\title{
Janusz Kaliński
}

\section{AUTOSTRADY NA EURO 2012}

Ważnym elementem modernizacji polskiej gospodarki jest rozbudowa i unowocześnienie infrastruktury transportowej. Szczególnie duże potrzeby występują w zakresie sieci drogowej, zarówno ze względu na szybko rozwijającą się motoryzację, jak i rosnący tranzyt. Podjęte w połowie lat 90 . XX w. prace nad stworzeniem systemu autostrad nie przyniosły do początku XXI w. zadowalających wyników. Wielkie nadzieje wiązano z członkostwem Polski w Unii Europejskiej i pozyskaniem funduszy europejskich, a następnie z organizacją Mistrzostw Europy w Piłce Nożnej (Euro 2012).

\section{Programy autostradowe}

Wybranie w kwietniu 2007 roku Polski i Ukrainy na organizatorów Mistrzostw Europy w Piłce Nożnej (Euro 2012) stało się wielkim wyzwaniem dla realizowanego od kilku lat programu budowy autostrad. Ustawą z dnia 7 września 2007 r. o przygotowaniu finałowego turnieju Mistrzostw Europy zobowiązano koalicyjny rząd Prawa i Sprawiedliwości (PiS) do opracowania wieloletniego programu przedsięwzięć niezbędnych do zapewnienia sukcesu organizacyjnego. Ważnym elementem programu była szeroko rozumiana sfera infrastruktury, szczególnie transportowej. Dnia 25 września 2007 roku Rada Ministrów przyjęła „Program budowy dróg krajowych na lata 2008-2012”. Przewidywał on stworzenie sieci autostrad o łącznej długości około $1676 \mathrm{~km}$, co oznaczało konieczność wybudowania $1093 \mathrm{~km}$ autostrad, z tego $620 \mathrm{~km}$ ze środków budżetowych (systemem tradycyjnym), a $473 \mathrm{~km}$ w ramach partnerstwa publiczno-prywatnego (PPP). Jako priorytety wyznaczono zakończenie budowy autostrady A1 na całej jej długości od Gdańska do granicy z Czechami, autostrady A2 na odcinku od Świecka na granicy z Niemcami do Warszawa i autostrady A4 od granicy zachodniej do granicy z Ukrainą.

Nowa propozycja niewiele różniła się od przedstawionego 19 stycznia 2006 roku przez ministra transportu i budownictwa „Programu budowy autostrad i dróg ekspresowych w latach 2006-2013", który zakładał osiągnięcie poziomu $1729 \mathrm{~km}$ autostrad. Natomiast nieco zmodyfikowane były priorytety wynikające $\mathrm{z}$ 
organizacji Euro 2012. Zrezygnowano ze wschodniego odcinka A2 Warszawa-Siedlce, a wprowadzono zadanie wcześniejszego dojścia z autostradą A4 do granicy z Ukrainą. Zdaniem ekspertów wraz z przyznaniem Polsce organizacji Euro 2012 zdecydowanie wzmocniony został priorytet budowy autostrad. Jednak, jak twierdził Janusz Piechociński, wiceprzewodniczący Sejmowej Komisji Infrastruktury, ucierpiały na tym plany budowy dróg ekspresowych.

Jesienią 2007 roku przygotowania do Euro 2012 przeszły w ręce nowego rządu koalicyjnego Platformy Obywatelskiej i Polskiego Stronnictwa Ludowego (PO-PSL). W exposé premiera Donalda Tuska znalazły się stwierdzenia krytyczne wobec dotychczasowego tempa budowy autostrad. Jako główne przyczyny artykułowane były bariery prawne i proceduralne, brak decyzyjności organów biurokratycznych, złe zarządzanie i niedostatek środków finansowych. Premier akcentował konieczność sprawniejszej realizacji projektowanych inwestycji i lepsze wykorzystanie dostępnych środków finansowych. Jako zmianę, w stosunku do polityki autostradowej rządów PiS, podkreślał niezbędność rozwinięcia współpracy z kapitałem prywatnym w ramach PPP, przy dominacji funduszy unijnych i środków budżetowych.

To ostatnie stwierdzenie było nawiązaniem do wyrażanej przez poprzedni rząd nieufności wobec kapitału prywatnego. Koalicja PO-PSL w systemie PPP dostrzegała pozytywy związane $\mathrm{z}$ wyłączeniem większości kosztów budowy z finansów publicznych, z szybszą budową dróg i lepszym nadzorem inwestorskim. Jako zjawiska negatywne traktowała wyższy koszt, a w konsekwencji wyższe opłaty dla użytkowników dróg, konieczność wyrównywania przez państwo strat inwestora i ograniczoną kontrolę rządu nad autostradami. Wiosną 2008 roku premier Tusk mówił o kilku błędnych decyzjach dotyczących autostrad, które miały być skorygowane. Według szefa rządu „Budowę autostrad traktujemy nie jako rutynę urzędniczą, lecz jako prawdziwe bojowe zadanie do wykonania”.

W 2009 roku rząd podtrzymał docelowy program stworzenia w Polsce około $2000 \mathrm{~km}$ autostrad, a minister infrastruktury Cezary Grabarczyk zapowiedział, że w związku z Euro 2012 powstanie sieć ponad $1600 \mathrm{~km}$ autostrad. Oznaczało to konieczność wybudowania do maja 2012 roku 906 km nowych dróg samochodowych. Do otwarcia mistrzostw Europy miały być gotowe autostrady A1, A2 od granicy z Niemcami do Warszawy, A4, A6 (obwodnica autostradowa Szczecina), A8 (obwodnica autostradowa Wrocławia) i A18 (Olszyna na granicy z Niemcami - węzeł Krzyżowa na A4).

Przygotowanie i realizacja programu autostradowego na Euro 2012 przechodziły silne perturbacje. Władze transportowe podkreślały trudności finansowe i wykonawcze związane $\mathrm{z}$ deficytem zdolności przerobowych firm budowlanych. Wbrew zapowiedziom rządu o zwiększeniu roli kapitału prywatnego, pojawiły się 
pogłoski o możliwości zerwania rozmów z koncesjonariuszami i podjęcia przez państwo budowy dróg ekspresowych zamiast autostrad. Pozytywnym zjawiskiem było przyspieszenie prac legislacyjnych, których efektem miało być zlikwidowanie barier utrudniających realizację programu autostradowego.

Zgodnie z zapowiedziami rządu 4 września 2008 roku nastąpiła nowelizacja ustawy o szczególnych zasadach przygotowania i realizacji inwestycji w zakresie dróg publicznych. Dzięki noweli połączono dwie dotychczas obowiązujące decyzje, o ustaleniu lokalizacji drogi i o pozwoleniu na budowę, w jedną - decyzję o zezwoleniu na realizację inwestycji drogowej. Spodziewanym rezultatem miało być skrócenie czasu na wydanie decyzji o wejściu na budowę z pięciu do trzech miesięcy. Stworzono także korzystniejsze warunki finansowe dla właścicieli przejmowanych nieruchomości. Nowa ustawa dostosowała również czas obowiązywania przepisów do perspektywy finansowej Unii Europejskiej na lata 2007-2013.

Dzięki ustawie dokonano korekt w Prawie zamówień publicznych w celu eliminowania przypadków blokowania wielkich inwestycji w wyniku wykrycia drobnych usterek formalnych w dokumentacji przetargowej. Istotną zmianą było odejście od lekceważenia napomnień Komisji Europejskiej w sprawie wdrożenia norm środowiskowych. Ustawą z dnia 3 października 2008 r. o udostępnianiu informacji o środowisku i jego ochronie, udziale społeczeństwa w ochronie środowiska oraz o ocenach oddziaływania na środowisko i ustawą z dnia 3 października $2008 \mathrm{r}$. o zmianie ustawy o ochronie przyrody oraz niektórych innych ustaw doprowadzono do spełniania przez inwestycje autostradowe wymagań środowiskowych UE, co w przeszłości było powodem opóźnień w realizacji wielu zaawansowanych projektów i zwiększało ryzyko utraty środków unijnych. W lipcu 2008 roku na zlecenie Ministerstwa Infrastruktury powstała „Prognoza oddziaływania na środowisko dla programu budowy dróg krajowych na lata 2008-2012”.

Dokonano także zmian organizacyjnych w Generalnej Dyrekcji Dróg Krajowych i Autostrad (GDDKiA), wyodrębniając: Departament Środowiska, Departament Projektów Unijnych i Monitoringu, Biuro Audytu Wewnętrznego i Kontroli oraz Departament Technologii. Zadaniem tego ostatniego było zwiększenie nadzoru nad jakością wykonywanych prac. Wdrożono także nowe procedury sprzyjające kulturze organizacyjnej.

Optymizm wokół budowy autostrad, który zrodził się po 2004 roku i nabrał wigoru w związku z przygotowaniami do Euro 2012, zaczęły studzić problemy finansowe Polski w latach 2009-2012, związane ze światowym kryzysem finansowym i polityką oszczędnościową UE. W końcu 2010 roku, w związku z nowelizacją prawa o finansach publicznych, powstała konieczność opracowania nowego programu drogowego. „Program budowy dróg krajowych na lata 2011-2015”, przyjęty przez Radę 
Ministrów 25 stycznia 2011 roku, zastąpił analogiczny dokument z września 2007 roku, „Program... 2011-2015” określił skorygowane cele i priorytety inwestycyjne, poziom i źródła finansowania oraz listę zadań. Szczegóły planowania finansowego i rzeczowego obejmowały lata 2011-2013. Dalsze zadania miały być włączone do „Programu... 2011-2015” po jego analizie w 2012 roku. Według nowych ustaleń do 2013 roku zamierzano wybudować 810,4 km autostrad (łącznie z odcinkami budowanymi w systemie koncesyjnym o długości 168,3 km). W efekcie miała być gotowa na całej długości autostrada A4, autostrada A2 od granicy zachodniej do Warszawy, zaś dalej na wschód obwodnica Mińska Mazowieckiego oraz autostrada A1 od Gdańska do Piotrkowa Trybunalskiego i jej odcinek południowy od Pyrzowic do granicy z Czechami. Po 2013 roku zamierzano zbudować fragment A1 Piotrków Trybunalski-Pyrzowice oraz A2 od Warszawa do granicy z Białorusią. W końcu okresu objętego „Programem... 2011-2015” sieć autostradową tworzyłyby magistrale A1 i A4, niedokończona na odcinku wschodnim A2 i odgrywające pomocniczą rolę A6 i A8. Nowy program autostradowy stanowił regres w stosunku do planów rządu Donalda Tusk z 2008 roku, gdyż oznaczał rezygnację z ambitnego projektu zbudowania na Euro 2012 całej autostrady A1 i uruchomienia A18. Powodem zatrzymania prac na autostradzie A18 było przesunięcie jej finansowania ze środków unijnych z perspektywy 2007-2013 na perspektywę budżetową 2014-2020.

\section{Finansowanie i prace przygotowawcze}

Podstawowymi źródłami finansowania „Programu budowy dróg krajowych na lata 2008-2012”, którego koszt szacowano na 18,2 mld zł, był budżet państwa, Krajowy Fundusz Drogowy (KFD) ${ }^{1}$ i środki unijne. W połowie 2009 roku, w związku nowelizacją ustawy o autostradach płatnych, podstawową rolę w krajowym finansowaniu autostrad przejął KFD. Instrumentami wykorzystania pomocy UE pozostały Program Operacyjny Inrafrastruktura i Środowisko (POIiŚ) i Fundusz Spójności (FS).

1 Środki finansowe KFD pochodziły głównie z opłaty paliwowej, odsetek z tytułu oprocentowania środków Funduszu, przychodów ze sprzedaży akcji i udziałów w spółkach uzyskanych od Skarbu Państwa, środków pochodzących z opłat za przejazdy pobieranych przez GDDKiA, wpływów uzyskanych przez GDDKiA z tytułu odpłatnego udostępniania nieruchomości nabytych na cele budowy dróg, środków pochodzących ze źródeł zagranicznych nie podlegających zwrotowi, środków z kredytów lub pożyczek zaciągniętych na rzecz Funduszu przez Bank Gospodarstwa Krajowego i wpływów z obligacji zaciągniętych na rzecz Funduszu przez BGK. 
Na początku 2008 roku rząd wydał rozporządzenie w sprawie ustalenie „Programu rzeczowo-finansowego dla inwestycji drogowych realizowanych z wykorzystaniem środków KFD na 2008 rok". Na autostradzie A2 finansowano z tych środków odcinek między węzłami Stryków (Stryków II) a Łódź Północ (Stryków I), zaś na A4 odcinek Wieliczka-Szarów. Jednak w listopadzie, pod wpływem odczuwanych konsekwencji światowego kryzysu finansowego, dokonano korekty programu, zmniejszając jego kwotę do $654 \mathrm{mln}$ zł, na którą składały się środki budżetowe (214 mln zł) i KDF (440 mln zł).

Na budowę autostrad w 2009 roku rząd przeznaczył aż $1686 \mathrm{mln}$ zł, z których tylko 78 mln zł pochodziło z KFD, zaś pozostała część z budżetu państwa. Środki skierowano na budowę węzła Łódź Północ na skrzyżowaniu autostrad A1 i A2 oraz budowę odcinka A1 z Sośnicy do Gorzyczek. W maju kwotę podniesiono do 1758 mln zł z przeznaczeniem 70 mln zł na budową ważnego odcinka autostrady A2 Łódź Północ-Konotopa, doprowadzającego ruch do Warszawy. Budowa miała być prowadzona w systemie tradycyjnym w związku z załamaniem się negocjacji ze spółkami zabiegającymi o koncesje. Dalsze 2 mld zł na budowę dróg w 2009 roku miały pochodzić z kredytów Europejskiego Banku Inwestycyjnego (EBI).

W miarę jak zbliżał się termin Euro 2012 narastały problemy z finansowaniem, budową i eksploatacją autostrad w systemie koncesyjnym. Opóźniały się prace na północnym odcinku autostrady A1 (Gdańsk) Rusocin-Nowe Marzy (90 km) realizowanym na podstawie umowy GDDKiA z Gdańsk Transport Company (GTC SA) podpisanej jeszcze w sierpniu 2004 roku. Jego koszt, w wysokości $768 \mathrm{mln}$ euro, miał pokryć kredyt z EBI i Nordic Investment Bank, gwarantowany przez KFD. Po objęciu władzy przez PO podpisano drugą umowę z GTC SA na budowę i eksploatację następnego odcinka A1 Nowe Marzy-Czerniewice (Toruń). Dodatkowo, pod koniec 2008 roku rząd podjął decyzję o udzieleniu GTC SA gwarancji w maksymalnej wysokości 1,28 mld zł, umożliwiających zaciągnięcie kredytów w EBI, Nordic Investment Bank i AB Svensk ExportKredit na częściowe sfinansowanie budowy drugiego odcinka autostrady A1 długości $62 \mathrm{~km}$. Kosztorys drugiego odcinka A1 opiewał na kwotę 938 mln euro i obejmował budowę autostrady Nowe Marzy-Lubicz, z przejściem przez Wisłę koło Grudziądza oraz modernizację odcinka Lubicz-Czerniewice, $\mathrm{z}$ dokończeniem budowy mostów przez Drwęcę i Wisłę w rejonie Torunia. Wykonawcą było konsorcjum GTC NDI, Skanska, Intertoll i Laing Road. Uroczystego otwarcia budowy na pierwszym kilometrze przyszłej autostrady dokonał minister infrastruktury Cezary Grabarczyk pod koniec sierpnia 2008 roku.

W czerwcu 2009 roku zakończono negocjacje między Ministerstwem Infrastruktury a Autostradą Wielkopolską SA II (AW SA II) w sprawie finansowania i budowy odcinka autostrady A2 Świecko-Nowy Tomyśl, długości 105,9km. AW SA 
II powstała jako spółka celowa, w której głównym udziałowcem był Kulczyk Holding SA. Skarb Państwa udzielił spółce gwarancji kredytowych i wydzierżawił AW SA II niezbędne grunty, powierzając wybudowanie autostrady w ciągu dwuipół roku oraz prowadzenie eksploatacji przez kolejne dwadzieścia pięć lat. W czasie trwania koncesji budżet państwa otrzymać miał około 1,3 mld zł z tytułu podatków VAT i CIT. Wpływy z opłat za przejazd miały trafiać do Skarbu Państwa, a spółce, podobnie jak GTC SA, zagwarantowano opłatę miesięczną za zapewnienie dostępności jej użytkownikom i umożliwiającą spłatę kredytów.

Środki finansowe na budowę odcinka Świecko-Nowy Tomyśl, łącznie 1,6 mld euro, pochodziły z kredytu EBI ( 1 mld euro), kredytów 11 polskich i zagranicznych banków komercyjnych (400 mln euro) oraz środków własnych Spółki (186 mln euro). Zgodę na państwową pomoc udzieliła UE, co było podstawą wypłat $\mathrm{z}$ kredytu udzielonego AW SA II przez EBI. Pierwsza transza została wypłacona, mimo że nie spełniono wszystkich warunków związanych z ochroną środowiska przy budowie tej autostrady. Tymczasem graniczyła ona lub przecinała m.in. Łagowski Park Krajobrazowy, Dolinę Ilanki i Dolinę Leniwej Obry.

Generalnym wykonawcą projektu została spółka A2Strada, z głównymi udziałowcami Kulczyk Holding SA i Strabag AG. Autostrada, której termin oddania do użytku ustalono na jesień 2011 roku, miała otrzymać nawierzchnię z betonu o dużej szorstkości. Zaprojektowana dla dwóch pasów ruchu w obydwu kierunkach, posiadała odpowiednie rezerwy do rozbudowy do trzech pasów. W lipcu 2009 roku minister infrastruktury C. Grabarczyk uczestniczył w uroczystym rozpoczęciu budowy autostrady A2 w kierunku granicy zachodniej.

Bez powodzenia przebiegało wyłanianie koncesjonariuszy dla odcinków Łódź Północ-Konotopa na A2 i Stryków-Pyrzowice na A1. Wymienione odcinki miały być zbudowane do 2010 roku. Przyjęty dla przyszłych umów system „projektuj i buduj” miał za zadanie skrócenie czasu realizacji inwestycji dzięki zastąpieniu odrębnych postępowań na zaprojektowanie i wykonawstwo jedną procedurą. Jednakże, w warunkach światowego kryzysu finansowego, pojawiły się trudności z uzyskaniem finansowania przez prywatne spółki. W przypadku przetargu na budowę odcinka autostrady A2 Łódź Północ-Konotopa przeciągały się negocjacje z dwoma podmiotami: Autostradą Mazowsze SA (spółka Stalexport Autostrada Dolnośląska SA i włoskiej firmy Atlantia SpA) i Autostradą Południe SA (konsorcjum firm Cintra Concessiones, Budimeksu i Ferrovial-Agroman). Brak środków niezbędnych do realizacji inwestycji przez spółki spowodował decyzję rządową, że autostrada będzie finansowana przez Skarb Państwa z kredytu EBI, a GDDKiA rozpisze nowe przetargi.

Na początku października 2009 roku GDDKiA rozstrzygnęła przetarg na projekt i budowę odcinka A2 od węzła Łódź Północ do Konotopy. Autostrada, długości 91 
$\mathrm{km}$, została podzielona na pięć odcinków A (29,2 km), B (17 km), C (20 km), D (17,6 $\mathrm{km}), \mathrm{E}(7,1 \mathrm{~km}),(\mathrm{A}$ - najbliżej Łodzi, a E - najbliżej Warszawy), dla których prowadzono oddzielne postępowania przetargowe. Budowa odcinków A i C przypadła konsorcjum pod kierunkiem China Overseas Engineering Group Co. Ltd (Covec). Odcinek B miało zbudować konsorcjum pod kierunkiem Mostostalu Warszawa SA, D - firma Strabag Sp. z o.o., a E - konsorcjum pod kierunkiem Budimex-Dromex SA. Na budowę autostrady między Łodzią a Warszawą przeznaczono 5,7 mld zł. Jednak w wyniku przetargów uzyskano cenę 3,2 mld zł, co dało oszczędności na kwotę 2,5 mld zł. Proces projektowania i przygotowania do budowy ruszył na jesieni 2009 roku, a roboty budowlane nabrały tempa w 2010 roku. Termin oddania do użytku wszystkich odcinków ustalono na maj-czerwiec 2012 roku. Wprawdzie pojawiły się protesty ekologów dotyczące odwodnienia autostrady i jej przejścia w rejonie Pruszkowa oraz problemy z wykupem niewielkiej części działek, jednak GDDKiA uważała, że nie przeszkodzi to w oddaniu autostrady przed Euro 2012.

W styczniu 2009 roku podpisano umowę na budowę $180 \mathrm{~km}$ odcinka autostrady A1 Łódź Północ-Pyrzowice w systemie PPP. Kosztem 7,5 mld zł konsorcjum Autostrada Południe SA (AP SA) miała zbudować do 31 maja 2012 roku odcinki Łódź Północ-Tuszyn oraz Tuszyn-Częstochowa, śladem istniejącej autostrady Tuszyn-Piotrków Trybunalski i drogi krajowej nr 1 Piotrków Trybunalski-Częstochowa. Z uwagi na fakt, że na odcinku Częstochowa-Pyrzowice (56 km) autostrada miała przebiegać przez tereny silnie zurbanizowane, odcinek ten miał powstać później, do końca 2013 roku. Oznaczało to faktyczną rezygnację ze zbudowania całej A1 na Euro 2012, czego nie ujawniano w programie autostradowym z 2009 roku. Wstępny kontrakt na wykonanie całej inwestycji zawarło konsorcjum firm Ferrovial-Agroman i Budimex-Dromex. We wrześniu 2009 roku koncesjonariusz uzyskał z EBI kredyt 1,1 mld euro, natomiast przedłużały się rozmowy $\mathrm{z}$ bankami na potrzebne jeszcze 600 mln euro. Ponieważ 22 stycznia 2010 roku minął ustalony termin, koncesjonariusz utracił możliwość budowy.

W tej sytuacji władze podjęły decyzję o budowie odcinka Łódź Północ-Pyrzowice w systemie budżetowym. Dnia 21 kwietnia 2010 roku GDDKiA ogłosiła przetarg na wybór projektanta i wykonawcy budowy pierwszego fragmentu Łódź Północ-Tuszyn. Inwestycja obejmowała budowę nowej autostrady na długości 38,6 km oraz przebudowę istniejącego odcinka o długości 1,4 km. Do przetargu przystąpiło 11 wykonawców, a najtańszą ofertę złożyło konsorcjum firm z liderem Polimex-Mostostal SA. Zaproponowana cena wynosiła 1,2 mld zł i była o $42 \mathrm{mln}$ niższa od preliminowanej przez GDDKiA. Mniej korzystnie przedstawiały się inne elementy kontraktu, szczególnie odnoszące się do czasu trwania robót. Termin ukończenia inwestycji w połowie 2013 roku oznaczał roczne opóźnienie w stosunku do 
„Programu budowy dróg krajowych na lata 2008-2012”, a przede wszystkim uniemożliwiał wykorzystanie tego odcinka autostrady A1 w okresie trwania Euro 2012.

Dłużej przeciągały się prace decyzyjne i przygotowawcze na liczącym $139 \mathrm{~km}$ odcinku Tuszyn-Pyrzowice. Na początku 2011 roku GDDKiA podpisała umowę na wykonanie dokumentacji projektowej dla południowej części autostrady ze spółkami Tebodin Poland Sp. z o.o. i Mosty Katowice Sp. z o.o. W Dyrekcji Generalnej rozważano także różne warianty finansowe i projektowe, m.in. ograniczenie autostrady do odcinka Częstochowa-Pyrzowice. Istotnym powodem zmian, a w rezultacie narastania opóźnień, były nowe regulacje unijne dotyczące udziału budżetu państwa w finansowaniu projektów PPP.

Negatywne doświadczenia $\mathrm{z}$ budową $\mathrm{w}$ systemie koncesyjnym odcinków autostradowych Łódź Północ-Konotopa i Łódź Północ-Pyrzowice wyhamowały przygotowania do budowy w systemie PPP autostrady A2 na wschód od Warszawy. Przewidywano jednak, że po likwidacji skutków światowego kryzysu finansowego nastąpi powrót do idei partnerstwa kapitału publicznego i prywatnego. Tymczasem umowy podpisane z prywatnymi koncesjonariuszami dowodziły wysokich kosztów budowy autostrad. W przypadku odcinka A1 Nowe Marzy-Czerniewice koszt jednego kilometra kształtował się na poziomie 11,7 mln euro, zaś odcinka A2 Świecko-Nowy Tomyśl aż 15,2 mln euro. Budowane wcześniej przez państwo autostrady, poza górnośląskimi odcinkami A4 Sośnica-Wirek (9,7 mln euro) i Wirek-Chorzów Batory (12,7 mln euro), były zdecydowanie tańsze. Koszt jednego kilometra autostrady A4 Zgorzelec-Krzyżowa wyniósł 6,1 mln euro, a Nogowczyce-Kleszczów 3,9 mln euro.

Mimo chęci władz przerzucenia ciężaru finansowania autostrad na kapitał prywatny dominowały inwestycje finansowane przez budżet i KFD z poważnym udziałem środków unijnych. W tym trybie w maju 2008 roku zawarto umowę ze spółką J\&P-Avax Polska SA na budowę wielopoziomowego węzła Gliwice-Sośnica na skrzyżowaniu autostrad A1 i A4. Jego koszt w wysokości 853 mln częściowo pokrywany był z FS. Umowę z konsorcjum Strabag Sp. z o.o. i Heilit-Woerner Budowlana Sp. z o.o. na kolejny odcinek A1 Bełk-Świerklany podpisano w sierpniu. Jego koszt sięgający 285,2 mln euro w 66\% pokrył FS. W listopadzie podpisano kontrakt $\mathrm{z}$ konsorcjum Alpine Mayreder Bau Gmbh, Alpine Bau Deutschland AG, Alpine stavebni spolećnost Cz, s.r.o. na odcinek Świerklany-Gorzyczki na granicy z Czechami. Koszt przedsięwzięcia wartości 273 mln euro w 66\% pokrywał FS. Projekt miał być zakończony po dwudziestu sześciu miesiącach od chwili rozpoczęcia budowy.

Pojawiły się jednak problemy, według GDDKiA na jesieni 2009 roku zaawansowanie prac między Świerklanami a Gorzyczkami znacznie odbiegało od harmonogramu. Dyrekcja Generalna w grudniu odstąpiła od kontraktu z winy wykonawcy, co potwierdził sąd. Dnia 1 kwietnia 2010 roku ogłoszono nowy przetarg i przesunięto 
termin zakończenia prac do końca marca 2012 roku. W przetargu rozstrzygniętym 13 sierpnia 2010 roku zwyciężyła Alpine Bau GmbH. O ponownym zwycięstwie firmy przesądziło zaproponowanie ceny o $292 \mathrm{mln}$ zł niższej od preliminowanej przez GDDKiA.

Przywrócenie wykonawcy nie zahamowało pasma wzajemnych oskarżeń dotyczących jakości projektowania i realizacji. W centrum sporu znalazła się budowa mostu w miejscowości Mszana, który wykonawca określał jako źle zaprojektowany, a inwestor dostrzegał wady procesu budowlanego, potwierdzone przez awarie. Dopiero w połowie 2012 roku Alpine Bau GmbH zadeklarowała budowę mostu na A1 zgodnie z projektem i uwagami nadzoru inwestycyjnego. Ocenia się, że problemy z wykonawcą na odcinku autostrady A1 ze Świerklan do Gorzyczek opóźniły jego realizację o dwa lata. Stanowiły jednocześnie wstęp do fali konfliktów na linii GDDKiA-wykonawcy, jakie ujawniły się po 2009 roku.

Kolejną umowę na autostradzie A1 podpisano w marcu 2009 roku z konsorcjum firm Polimex-Mostostal, Dopravostav a.s. (Słowacja), Eurovic Polska i Przedsiębiorstwo Robót Drogowych i Mostowych Kędzierzyn-Koźle. Umowa dotyczyła budowy odcinka Zabrze Zachód (Maciejów)-Sośnica (Gliwice), wartości 1,1 mld zł. W czerwcu zawarto kontrakt wartości 1,3 mld zł z Dragados SA na odcinek Piekary Śląskie-węzeł Zabrze Zachód, a miesiąc później na odcinek Pyrzowice-Piekary Śląskie, który miał zrealizować Budimex Dromex SA z Mostostalem Warszawa SA kosztem 1,8 mld zł.

W końcu maja 2010 roku sygnowano umowę na wykonanie drugiego co do wielkości węzła autostradowego w Polsce. Węzeł Łódź Północ na skrzyżowaniu autostrad A1 i A2 miała zbudować do końca listopada 2011 roku firma Budimex SA kosztem $307,6 \mathrm{mln}$ zl.

Umowy na kolejne odcinki A1, między Toruniem a Kowalem, podpisano w połowie czerwca. Odcinki Czerniewice-Odolin i Odolin-Brzezie, o łącznej długości 34,4 km, powierzono konsorcjum firm polskich i irlandzkich z liderem SRB Civil Engineering Ltd, zaś odcinek Brzezie-Kowal (29,5 km) - temu samemu konsorcjum z liderem PBG SA. Dalej na południe odcinek Kowal-Sójki, o długości 30 km, powierzono konsorcjum firm SRB Civil Engineering Ltd (Irlandia), John Sisk\&Sons Ltd (Irlandia), Roadbridge (Irlandia) i Budbaum SA (Białystok). Odcinek SójkiKotliska, o długości $65 \mathrm{~km}$, miało budować konsorcjum firm Poldim SA (Tarnów), Bögl \& Krýsl. k.s. (Czechy) i Bogl\&Krysl Polska Sp. z o.o. Odcinek Kotliska-Piątek $(9 \mathrm{~km})$ powierzono konsorcjum firm Sando Budownictwo Polska Sp. z o.o. i Construcciones Sanchez Dominiguez-Sando SA (Hiszpania), a odcinek Piątek-Łódź Północ (21 km) - konsorcjum: Johann Bunte Bauuternehmung GmBH\&Co.KG (Niemcy), Bunte Polska Sp. z o.o., Przedsiębiorstwo Robót Mostowych „Mosty-Łódź” 
SA, Przedsiębiorstwo Budowy Dróg i Mostów ERBEDIM Sp. z o.o. (Piotrków Tryb.) i Przedsiębiorstwo Usług Technicznych ITERCOR Sp. z o.o. (Zawiercie). W umowie podpisanej w lipcu termin zakończenia inwestycji ustalono na kwiecień 2012 roku.

Pod koniec sierpnia 2009 roku, w obecności ministra Grabarczyka, oficjalnie zainaugurowano budowę obwodnicy Mińska Mazowieckiego. Obwodnica długości $21 \mathrm{~km}$ stanowiła pierwszy na wschód od Warszawy odcinek autostrady A2. Budowę, zgodnie z kontraktem podpisanym 9 lipca 2009 roku, prowadziło konsorcjum, w którego skład weszły: Przedsiębiorstwo Budowy Dróg i Mostów Sp. z o.o. Mińsk Mazowiecki, Astaldi S.P.A. Włochy, Przedsiębiorstwo Robót Drogowych „Regionalne Drogi Podlaskie" Sp. z o.o. Siedlce, Przedsiębiorstwo Budownictwa Lądowego „Mazowieckie Mosty” Sp. z o.o. i Warszawskie Przedsiębiorstwo Mostowe Mosty SA. Inwestycja miała być zakończona do końca lipca 2012 roku, a jej wartość wynosiła $567,4 \mathrm{mln}$ zł.

$\mathrm{Na}$ autostradzie A4 pod koniec października 2009 roku rozstrzygnięto przetarg na budowę odcinka Szarów-Brzesko. Uczestniczyło w nim siedem firm i konsorcjów. Najniższą cenę zaproponowało polsko-słowacko-czeskie konsorcjum firm Polimex-Mostostal SA, Doprastav AS i Metrostav as. Cena na poziomie $779 \mathrm{mln}$ zł okazała się o blisko połowę niższa od przyjętej w kosztorysie inwestorskim.

$\mathrm{Na}$ początku listopada $\mathrm{w}$ rzeszowskim oddziale GDDKiA została podpisana umowa na budowę odcinka autostrady A4 Jarosław-Korczowa (granica państwa). Fragment $\mathrm{z}$ Jarosławia do Radymna wybuduje Budimex Dromex SA i hiszpański Ferrovial Agroman za 970 mln zł, a z Radymna do Korczowej grecka firma J\&P Avax za $820 \mathrm{mln}$ zł. Przyjęty kosztorys okazał się o $650 \mathrm{mln}$ zł niższy od przygotowanego przez GDDKiA.

Pod koniec listopada 2009 roku w krakowskim oddziale GDDKiA rozstrzygnięto przetarg na budowę 21-kilometrowego odcinka autostrady A4 Brzesko-Tarnów Zachód (Wierzchosławice). Zwyciężyło polsko-macedońskie konsorcjum firm NDI SA z Warszawy oraz SB Granit SA ze Skopje, które złożyło ofertę w wysokości $622,5 \mathrm{mln}$ zł. Zaproponowana suma była o połowę niższa od ujętej w kosztorysie inwestorskim. Dwóch spośród pozostałych uczestników przetargu oprotestowało rozstrzygnięcie. Sprawa trafiła do Krajowej Izby Odwoławczej, która orzekła, że stanowisko komisji przetargowej było słuszne. Podpisanie umowy nastąpiło na początku lutego 2010 roku.

W styczniu 2010 roku, w przetargu na odcinek Rzeszów Zachód-Rzeszów Północ, składający się z 4-kilometrowego odcinka autostrady A4 i drogi ekspresowej S19, wybrano ofertę złożoną przez konsorcjum firm z liderem - firmą Radko Sp. z o.o. oraz partnerami Autostrada Wschodnia Sp. z o.o. z Warszawy i Punj Lloyd Ltd z Indii. Budowa tego odcinka miała kosztować ponad $442 \mathrm{mln}$ zł, pochodzących 
z POIiŚ oraz z budżetu państwa. W tym samym miesiącu rozstrzygnięto przetarg na odcinek Tarnów Zachód-Tarnów Krzyż długości 13 km. Kontrakt wartości 542,8 mln zł uzyskała hiszpańska firma Dragados SA, która zobowiązała się wybudować autostradę w ciągu dwóch lat. Pod koniec lutego w rzeszowskim oddziale GDDKiA podpisano umowę na budowę odcinka od węzła Rzeszów Północ do węzła Rzeszów Wschód długości 6,9 km. Kontrakt wartości 439,5 mln zł, zdecydowanie niższy niż zakładał kosztorys inwestora, finansowany z POIiŚ oraz budżetu państwa, uzyskało polsko-hiszpańskie konsorcjum firm Mostostal Warszawa SA i Acciona Infraestructuras. Konsorcjum miało wybudować odcinek północnej obwodnicy Rzeszowa w ciągu osiemnastu miesięcy.

Umowę na budowę 33-kilometrowego odcinka od węzła Dębica Pustynia do węzła Rzeszów-Zachód podpisano 10 maja 2010 roku. Kontrakt wartości 1,73 mld zł, finansowany z POIiŚ i budżetu państwa, uzyskała firma Budimex SA, która zobowiązała się do ukończenia inwestycji w czerwcu 2012 roku.

Na początku lipca nastąpiło podpisanie umowy na budowę 35-kilometrowego odcinka autostrady A4 od węzła Tarnów Krzyż do węzła Dębica Pustynia. Przetarg wygrało irlandzko-polskie konsorcjum firm Siac Construction Ltd, PBG SA, Arrivia SA i Hydrobudowa Polska SA. Wartość kontraktu, sfinansowanego z POIiŚ i budżetu państwa, wyniosła 1,75 mld zł, a jego zakończenie ustalono na czerwiec 2012 roku. Umowę na ostatni, 41-kilometrowy odcinek autostrady A4 Rzeszów Wschód-Jarosław podpisano 23 września 2010 roku. Wyłonionym w drodze przetargu wykonawcą było konsorcjum Polimex Mostostal SA i Doprastav a.s. (Słowacja). Inwestycja wartości 2,2 mld zł sfinansowana została ze środków POIiŚ i budżetu państwa.

Poza autostradami A1, A2 i A4, w sierpniu 2008 roku wybrano wykonawcę zaprojektowania i zbudowania wrocławskiej obwodnicy A8 długości 27 km. Kontrakty podpisano z konsorcjum firm Mostostal Warszawa SA i Acciona Infraestructuras SA, Budimex Dromex oraz konsorcjum Strabag Sp. z o.o., Heilit+Woerner, Dywidag Bau GmbH i Mostostal Warszawa. Obwodnica, której koszt obliczono na 3,8 mld zt, połączyć miała autostradę A4 z planowanymi drogami ekspresowymi S5 w kierunku Poznania i S8 w kierunku Warszawy.

Przytoczone informacje o rozstrzygniętych przetargach i rozpoczętych pracach wskazywały na zdecydowane przyspieszenie programu autostradowego $\mathrm{w}$ związku z organizacją Euro 2012. Dotyczyło to zarówno systemu koncesyjnego, jak i tradycyjnego. W 2007 roku sfinalizowano przetargi dla 55,3 km autostrad, zaś w 2008 roku - 211,4 km, w 2009 roku - 388,1 km, a w 2010 roku - 382,7 km. Ogółem od 2008 roku do 2010 roku podpisano umowy na budowę $982,2 \mathrm{~km}$ autostrad. Umowy przewidywały budowę głównie w systemie tradycyjnym, gdyż PPP objęto $168 \mathrm{~km}$ autostrad, co stanowiło zaledwie 15\% ogółu zobowiązań. Na autostradzie A1 
wyłoniono wykonawców dla odcinków Gdańsk-Toruń-Łódź-Tuszyn oraz Pyrzowice-Gorzyczki. Na autostradzie A2 dla odcinków Świecko-Nowy Tomyśl, ŁódźWarszawa (Łódź Północ-Konotopa) i autostradowej obwodnicy Mińska Mazowieckiego. Na A4 - dla odcinków Zgorzelec-Krzyżowa, Kraków-Korczowa na granicy z Ukrainą, a także obwodnicy Wrocławia (A8). Z pewnością był to największy $\mathrm{w}$ historii polskich autostrad przyrost decyzji inwestycyjnych, który budził optymizm co do możliwości szybkiego stworzenia w naszym kraju sieci nowoczesnych dróg samochodowych.

Optymizm podtrzymywał fakt, że za względu na utrzymujący się światowy kryzys finansowy wartość ofert korzystnie odbiegała od kwot, jakie na poszczególne fragmenty zamierzała przeznaczyć GDDKiA. Na autostradzie A1 na jej środkowe odcinki Czerniewice-Odolin-Brzezie-Kowal zamierzano wydać blisko 3 mld zł, natomiast zwycięskie oferty opiewały na 1,8 mld zł. Oszczędności sięgnęły blisko $40 \%$ preliminowanych kwot. Na czterech odcinkach między Kowalem a Strykowem oszczędności sięgnęły $774 \mathrm{mln}$ zł, co stanowiło blisko 24\% preliminowanej kwoty. Niższe od kosztorysu inwestora były oferty wykonawców na południowym odcinku A1 oraz odcinkach A4 Szarów-Brzesko, Brzesko-Tarnów Zachód, Rzeszów PółnocRzeszów Wschód i Jarosław-Korczowa. Według GDDKiA tylko w 2009 roku średnia cena uzyskana w przetargach była o $27 \%$ niższa od zakładanej w kosztorysach, co dało 8 mld zł oszczędności.

Duże różnice między kosztorysami inwestora i wykonawców, zauważane przez specjalistów, nie budziły odpowiednich refleksji po stronie władz drogowych. Tymczasem ich skutki finansowe, początkowo korzystne, wkrótce negatywnie zaważyły na realizacji programu autostradowego. Dołączyły się do nich problemy związane $\mathrm{z}$ wykonawstwem, środowiskowe i o charakterze losowym.

\section{Problemy realizacyjne}

Pod koniec 2010 roku trwały prace przy budowie 34 odcinków autostrad o łącznej długości 743,4 km. W systemie koncesyjnym na A1 Nowe Marzy-Czerniewice $(62,4 \mathrm{~km})$ i na A2 Świecko-Nowy Tomyśl (105,9km). Na A1 w końcu 2010 roku postęp prac o $13 \%$ wyprzedzał założenia harmonogramu. Równie sprawnie przebiegała realizacja A2 do granicy z Niemcami.

W systemie tradycyjnym budowano na A1 odcinki: Czerniewice-Odolion $(11,4 \mathrm{~km})$, Odolion-Brzezie $(23,1 \mathrm{~km})$, Brzezie-Kowal (29,5 km), Kowal-Sójki (30 km), Sójki-Kotliska (15,2 km), Kotliska-Piątek (9 km), Piątek-Łódź Północ 
(21 km), węzeł Łódź Północ (4,9km), Pyrzowice-Piekary Śląskie (16,1km), Piekary Śląskie-Zabrze Zachód (20,1km), Zabrze Zachód-Sośnica (Gliwice) $(6 \mathrm{~km})$, węzeł Sośnica (Gliwice) (2,2 km), Bełk-Świerklany (14,1 km) i Świerklany-Gorzyczki $(18,3 \mathrm{~km})$.

$\mathrm{Na}$ autostradzie A2 od czerwca 2010 roku trwały prace przygotowawcze na prestiżowym odcinku z Łodzi do Warszawy. Polegały one m.in. na wyburzeniu, w obecności ambasadora Chin i ministra Grabarczyka, wiaduktów zbudowanych w latach 70. w pobliżu Bolimowa, na częściowo zbudowanej autostradzie z Poznania do Warszawy. Wówczas prezes firmy Covec, która była odpowiedzialna za ten fragment mówił: „Mam nadzieję, że to będzie droga wielkiej przyjaźni polsko-chińskiej”. Oficjalne wejście na budowę A2 między Łodzią a Warszawą nastąpiło 14 lipca 2010 roku na odcinku E pod Pruszkowem. W październiku ruszyły prace na łódzkim odcinku autostrady, a w końcu 2010 roku w budowie był cały fragment od Strykowa do podwarszawskiej Konotopy. Kontynuowano także budowę obwodnicy autostradowej Mińska Mazowieckiego.

Na A4 budowa posuwała się na wszystkich jej wschodnich odcinkach: Szarów-Brzesko (23,1km), Brzesko-Tarnów Zachód (20,8km), Tarnów Zachód-Tarnów Krzyż (13 km), Tarnów Krzyż-Dębica Pustynia (34,8km), Dębica Pustynia-Rzeszów Zachód (32,7 km), Rzeszów Zachód-Rzeszów Północ (4km), Rzeszów Północ-Rzeszów Wschód (6,9km), Rzeszów Wschód-Jarosław (41,2km), Jarosław-Radymno $(24,5 \mathrm{~km})$ i Radymno-Korczowa $(22,6 \mathrm{~km})$. Trwały także prace na obwodnicy autostradowej Wrocławia (A8).

Poważnym zagrożeniem dla realizacji programu autostradowego były powtarzające się powodzie. Już na wiosnę 2010 roku oceniano, że opóźnienia mogą dochodzić do sześciu miesięcy, szczególnie w przypadku obwodnicy Wrocławia i odcinka autostrady A1 Piekary Śląskie-Zabrze Zachód. Na A1 w maju woda zalała maszyny, kontenery, konstrukcje wiaduktów i wytyczony ślad autostrady, straty sięgnęły $7 \mathrm{mln}$ zł. Powodzie były także powodem opóźnień na budowie odcinka A4 z Szarowa do Tarnowa, który częściowo zalały wody Dunajca i Raby.

Na dalsze opóźnienia wpłynęły problemy finansowe oraz jakościowe wykonawstwa. W sporządzonej przez Najwyższą Izbę Kontroli „Informacji o wynikach kontroli przygotowania Polski do organizacji finałowego turnieju Mistrzostw Europy w Piłce Nożnej UEFA Euro 2012" wskazano na niskie zaawansowanie finansowe w zakresie budowy kilku odcinków autostrad, których oddanie planowano przed Euro 2012. Na koniec 2010 roku zaawansowanie autostrady A18 oceniano zaledwie na 3\%, odcinka A1 Toruń-Łódź na 5\%, A4 Rzeszów-Korczowa na 6\%, A4 TarnówRzeszów na 7\%, A4 Szarów-Tarnów na 10\%, a odcinka A2 Łódź-Warszawa na 16\%. 
Ewidentne problemy skłoniły władze do przesunięcia terminu zakończenia budowy autostrady A18, odcinków A1 Toruń-Łódź oraz A4 Tarnów-Rzeszów i Rzeszów-Korczowa. Decyzje te oznaczały dotkliwą klęskę projektu uzyskania przed Euro 2012 ciągu autostradowego Gdańsk-granica z Czechami i od granicy niemieckiej do ukraińskiej.

Niepowodzenia programu autostradowego potwierdziły problemy, które ujawniły się także w 2011 i 2012 roku. Początkowo dotyczyły one wschodniej części autostrady A4. W lutym 2011 roku nastąpiło wypowiedzenie przez GDDKiA umowy z konsorcjum NDI SA-SB Granit SA na budowę odcinka węzeł Brzesko-węzeł Tarnów Zachód. Według Dyrekcji Generalnej winę za rozwiązanie umowy ponosił wykonawca, który dopuścił do wielomiesięcznego opóźnienia w realizacji kontraktu i nie płacił podwykonawcom. Podnoszono także kwestie nielegalnego zatrudniania macedońskich pracowników. Wykonawca z kolei przerzucał odpowiedzialność na GDDKiA, która jakoby nie uwzględniła postulatów finansowych, związanych ze wzrostem kosztów budowy, wywołanych stratami powodziowymi. W kwietniu konsorcjum porzuciło budowę, na którą weszła Komisja Inwentaryzacyjna. Dyrekcja przewidywała, że wykorzystując niektóre przepisy ustawy o zamówieniach publicznych, uda się wprowadzić jesienią 2011 roku nowego wykonawcę. Jednak stawiało pod znakiem zapytania budowę odcinka między Krakowem a Tarnowem przed Euro 2012.

Wykonawcą porzuconego odcinka zostało wybrane w drodze przetargu konsorcjum Heilit+Woerner Budowlana, Strabag, Poldim i Przedsiębiorstwo Inżynieryjne IMB-Podbeskidzie. Konsorcjum za $642 \mathrm{mln}$ zł zobowiązało się dokończyć prace na autostradzie do października 2012 roku. Pojawiły się jednak nowe problemy spowodowane upadłością uczestnika konsorcjum firmy Poldim. Dodatkowo niewypłacone przez nią podwykonawcom należności były powodem protestów i blokowania dróg.

Niedobre sygnały napływały także z innych odcinków A4 Rzeszów-Jarosław i Radymno-Korczowa. Na pierwszym konsorcjum Polimex-Mostostal SA i Doprastav a.s. notowały opóźnienia oraz problemy $\mathrm{z}$ realizacją inwestycji, w tym środowiskowe i finansowe. Na drugim grecka spółka J\&P Avax sygnalizowała możliwość rezygnacji z kontraktu na tle sporów z GDDKiA wokół stosowanych technologii i opóźnień w dostarczaniu dokumentacji. Strona polska akcentowała w sporze troskę o jakość budowanej autostrady.

Pod koniec maja 2012 roku GDDKiA zdecydowała o odstąpieniu od umowy na budowę odcinka Rzeszów Zachód-Rzeszów Północ, gdyż dotychczasowy wykonawca, polsko-indyjskie konsorcjum z liderem firmą Radko Sp. z o.o, wykazywał brak płynności finansowej. W rozstrzygniętym w połowie października 2012 roku nowym 
przetargu najniższą ofertę w wysokości 183 mln zł brutto przedstawił Budimex. Firma w ciągu czternastu miesięcy miała wykonać część nasypów i warstw konstrukcyjnych nawierzchni oraz dokończyć prace budowlane przy OUA i wykończeniowe.

W lipcu 2012 roku konsorcjum firm: SIAC Construction Ltd, PBG SA, APRIVIA SA i Hydrobudowa Polska SA, które nie wywiązywało się z zapisów kontraktowych, przestało budować odcinek Tarnów Krzyż-Dębica Pustynia, zażądało dopłaty 200 mln zł, a następnie odstąpiło od umowy. Konsorcjum zarzucało GDDKiA nierzetelne zarządzanie projektem i niewywiązywanie się z zobowiązań. Doprowadziło to do zerwania umowy przez Dyrekcję Generalną i podjęcia procedury wyboru nowego wykonawcy. Pod koniec listopada ogłoszono przetarg na dokończenie przerwanej budowy $\mathrm{z}$ terminem otwarcia ofert w połowie stycznie 2013 roku.

Latem 2012 roku, kiedy zbliżał się planowy termin oddania obiektów do użytku, zaawansowanie budowy odcinka Tarnów-Dębica oceniano na 50\%. Podobnie szacowano stan prac na odcinku od Radymna do przejścia granicznego w Korczowej. Gorzej było z odcinkiem Rzeszów Wschód-Jarosław zaawansowanym tylko w 38\% i odcinkiem Rzeszów Zachód-Rzeszów Północ.

Podobne problemy pojawiły się także na autostradzie A1 między Toruniem a Łodzią w związku konfliktem między GDDKiA i konsorcjum z udziałem irlandzkiej SRB Civil Engineering. Szczególnie silnie zarysował się spór na budowie między Czerniewicami a Kowalem, gdzie notowano znaczne odchylenia od harmonogramu robót. Początkowo wykonawca deklarował mobilizację na terenie budowy, ale wysuwał także roszczenia finansowe. We wrześniu 2012 roku doszło do zerwania umowy z winy irlandzkiego konsorcjum na realizację odcinków Czerniewice-Odolion i Odolion-Brzezie. Podobna sytuacja wystąpiła na odcinku Brzezie-Kowal, którego liderem była upadająca spółka PBG SA. GDDKiA zabezpieczyła teren budowy i w ciągu miesiąca przygotowała przetargi na wykonanie zagrożonych odcinków. Tymczasem SRB wystąpiła na drogę sądowa o prawie 1,2 mld zł odszkodowania od Generalnej Dyrekcji.

Pod koniec grudnia 2012 roku zostały otwarte oferty na dokończenie budowy autostrady A1 na odcinkach: Czerniewice-Brzezie i Brzezie-Kowal. Najniższe oferty cenowe złożyło konsorcjum firm z liderem Salini Polska Sp. z o.o. Wyniosły one kolejno $450 \mathrm{mln}$ zł i $608 \mathrm{mln}$ zł, a przyjęty czas realizacji od chwili podpisania umowy odpowiednio jedenaście i dwanaście miesięcy. Wznowienie prac budowlanych przewidziano na wiosnę 2013 roku.

Na odcinku Kowal-Łódź Północ wystąpił spór wokół technologii budowy autostrady. Strona polska nie akceptowała zmian, które obniżały koszty, ale nie gwarantowały odpowiedniej jakości, natomiast SRB domagała się dopłaty do zawartej umowy. Pojawiły się także problemy związane z niewypłacaniem przez irlandzkie 
konsorcjum należności podwykonawcom. Zaległości w płatnościach SRB Civil Engineering wobec podwykonawców na odcinkach Czerniewice-Odolion-Brzezie wynosiły około $33 \mathrm{mln}$ zł, zaś na odcinku Kowal-Sójki około $18 \mathrm{mln}$ zł.

W 2012 roku wystąpiły problemy ekologiczne na budowanej autostradzie A2 w rejonie Mińska Mazowieckiego. Siedliska płazów były powodem zmian w części projektów i procesu realizacyjnego. Sprawa była na tyle poważna, że stanowiła przejściowe zagrożenie dla wykorzystania środków unijnych.

Jednak prestiżowo największy konflikt wybuchł na autostradzie A2, na jej dwóch odcinkach realizowanych przez chińską firmę Covec. Na początku czerwca 2011 roku strona chińska poinformowała GDDKiA o zamiarze rezygnacji z budowy autostrady, a jednocześnie zaproponowała rozmowy na temat renegocjacji warunków umowy. Chińczycy sugerowali konieczność zwiększenia o 1,3 mld zł kwoty przeznaczonej na budowę. Władze polskie ustami premiera Tuska sprzeciwiły się zmianom w podpisanej umowie. Covec, który wcześniej nie wywiązywał się z zobowiązań finansowych wobec polskich podwykonawców, zszedł z budowy. Pod znakiem zapytania stanęło ukończenie na Euro 2012 połączenia autostradowego między Łodzią a Warszawą, a w zasadzie między Niemcami a stolicą Polski. W mediach pojawiły się opinie o niedostatecznym sprawdzeniu chińskiej firmy przed podpisaniem umowy i przyjęciu oferty z wyraźnie dumpingową ceną. Przypominano ostrzeżenia polskich fachowców wobec wykonawców z Dalekiego Wschodu, wyrażane m.in. przez Marka Michałowskiego, prezesa Polskiego Związku Pracodawców Budownictwa.

W nowej sytuacji GDDKiA zapowiedziała wystąpienie do strony chińskiej o wysokie odszkodowanie (741 mln zł), a jednocześnie przystąpiła do przygotowania wariantu zastępczego w celu uzyskania możliwości przejazdu autostradą przed Euro 2012. W tym celu pojawiły się inicjatywy polityczne zmierzające do zmian w prawie. Ich rezultatem była ustawa $\mathrm{z}$ dnia 30 marca 2012 r. o zmianie ustawy o szczególnych zasadach przygotowania i realizacji inwestycji w zakresie dróg publicznych. Ustawa zezwalała na dopuszczenie do ruchu drogi, która nie była w pełni ukończona, ale spełniała wymogi bezpieczeństwa budowlanego. $\mathrm{W}$ ten sposób narodził się termin „przejezdność”, szeroko spopularyzowany przez media, oznaczający możliwość korzystania z niewykończonej drogi.

Pod koniec czerwca 2011 roku uprawomocniła się decyzja GDDKiA o odstąpieniu od kontraktów z chińskim konsorcjum. Pozostało jednak wiele rozliczeń finansowych dotyczących podwykonawców, którzy nie otrzymali należnych wynagrodzeń, oraz z tytułu kar umownych. Ich egzekwowanie okazało się bardzo trudne i było powodem szeregu napięć i protestów ze strony pokrzywdzonych. Covec zdecydowanie odmawiał wypłacenia odszkodowania Generalnej Dyrekcji. 
W warunkach olbrzymiej presji terminu Euro 2012 przystąpiono do negocjacji z firmami, które zgłosiły chęć i gotowość dokończenia budowy. Z licznej grupy zainteresowanych wybrano francusko-polskie Konsorcjum Eurovia-Warbud i czesko-polskie konsorcjum Bögl a Krýsl-Dolnośląskie Surowce Skalne (DSS). Pierwsze konsorcjum podjęło się dokończenia odcinka długości około $29 \mathrm{~km}$ w pobliżu Łodzi za $989 \mathrm{mln}$ zł, drugie odcinka długości około $20 \mathrm{~km} \mathrm{w}$ rejonie Wiskitek za $756 \mathrm{mln}$ zł. W obu umowach przyjęto jako datę zakończenia robót 15 października 2012 roku, przy zapewnieniu "przejezdności” trasy do 31 maja 2012 roku. Kwota przyjęta w umowach na dokończenie autostrady o blisko 0,5 mld przekroczyła ustalenia umowy z Covec na jej zbudowanie.

Zagrożonemu odcinkowi autostrady A2 z Łodzi do Warszawy szczególną uwagę poświęcały władze transportowe. Organizowano wizyty na newralgicznych odcinkach i spotkania ministra transportu Sławomira Nowaka z wykonawcami autostrady. Na początku 2012 roku najbardziej zagrożony był odcinek C w pobliżu Wiskitek. Jego wykonawca, spółka DSS działająca z czeską firmą Bögl a Krýsl, zapewniała, że pomimo wewnętrznych problemów zapewni „przejezdność” autostrady na Euro 2012. Upadek firmy dolnośląskiej na wniosek firmy windykacyjnej sprawił, że na początku 2012 roku budowę odcinka C w pełni przejęli Czesi. Na cztery miesiące przed Euro 2012 zaangażowanie prac na tym newralgicznym odcinku sięgało zaledwie 43\%. Na odcinku porzuconym przez Chińczyków w okolicach Łodzi podobny wskaźnik wynosił $65 \%$. W tej sytuacji w GDDKiA tworzono wersje dojazdu z węzła Łódź Północ do Warszawy z wykorzystaniem odcinków D i E autostrady, które uznawano za niezagrożone.

Podwykonawcy DSS, którzy nie otrzymali należności, dołączyli do licznej grupy innych firm budowlanych, które znalazły się w podobnej sytuacji. Ich protesty, często związane z blokadą budów, zmusiły władze do zastosowania reguły solidarnej odpowiedzialności, która znalazła się w pospiesznie uchwalonej ustawie z dnia 28 czerwca 2012 r. o spłacie niektórych niezaspokojonych należności przedsiębiorców, wynikających z realizacji udzielonych zamówień publicznych. Do października 2012 roku GDDKiA, jako inwestor, korzystając ze środków KFD, wypłaciła z tego tytułu $370 \mathrm{mln}$ zł. Wypłaty dla podwykonawców, dokonywane z tytułu solidarnej odpowiedzialności, były potrącane z faktur dla generalnych wykonawców. 


\section{Wyniki realizacji programu autostradowego do końca 2012 roku}

Prace prowadzone przed 2008 rokiem i nowe decyzje inwestycyjne dały wymierne efekty w postaci ukończonych odcinków autostrad w okresie poprzedzającym Euro 2012. Wbrew pierwotnym założeniom, większe przyrosty nowoczesnych dróg uzyskano dzięki inwestycjom państwowym. W systemie koncesyjnym w październiku 2008 roku oddano do użytku odcinek autostrady A1 Rusocin-Nowe Marzy długości $90 \mathrm{~km}$. Uzyskany ciąg autostradowy Trójmiasto-Grudziądz posiadał $4 \mathrm{MOP}-\mathrm{y}$ i 6 węzłów drogowych.

Na drogach budowanych przez państwo przed końcem 2008 roku połączono węzły Stryków i Łódź Północ na autostradzie A2 oddalone o 1,7 km. W ten sposób powstał drugi w Polsce pod względem długości ciąg autostradowy Nowy Tomyśl-Stryków, liczący $250 \mathrm{~km}$. Autostrada A4 w połowie sierpnia 2009 roku dotarła do granicy z Niemcami. Stało się to możliwe dzięki otwarciu przez wicepremiera Grzegorza Schetynę i ministra Cezarego Grabarczyka odcinka Zgorzelec-Krzyżowa. Na autostradzie długości 51,4 km powstały trzy węzły drogowe i dwa MOP-y. W październiku został otwarty kolejny, liczący 19,9 km odcinek A4 z Krakowa (Wielicka) do Szarowa. W rezultacie uzyskano ciąg autostradowy od granicy zachodniej do wschodniego wylotu A4 z Krakowa o długości $446 \mathrm{~km}$.

Pierwsze rezultaty odnotowano na południowym odcinku A1, gdzie 23 grudnia 2009 roku przekazano do ruchu liczący 15,5 km odcinek Sośnica (Gliwice)-Bełk. Autostrada budowana w trudnych warunkach szkód górniczych uzyskała trzy pasy ruchu w każdym kierunku oraz trzy bezkolizyjne węzły. Przy drodze powstał jeden Punkt Poboru Opłat (PPO) i dwa MOP-y. Od 7 lipca 2010 roku kierowcy mogli skorzystać z rozbudowanego węzła Sośnica (Gliwice) na skrzyżowaniu A1 z A4. Z kilkumiesięcznym opóźnieniem, spowodowanym wiosennymi powodziami, 15 grudnia 2010 roku uruchomiono pierwszy fragment, a 21 kwietnia 2011 roku drugi fragment odcinka Bełk-Świerklany (długości 14,1 km) przybliżający autostradę do granicy z Czechami.

W końcu 2010 roku oddano do użytku fragment wrocławskiej obwodnicy autostradowej (A8) od łącznika Kobierzyce do skrzyżowania z autostradą A4 (węzeł Wrocław Południe). W maju 2011 roku dopuszczono do ruchu samochodowego odcinek węzeł Wrocław Południe-węzeł Lotnisko. Licząca 14,5 km trasa składała się z drogi głównej i ekspresowej oraz liczącej 7,4 km autostrady.

W latach 2008-2010, łącznie w systemie tradycyjnym i koncesyjnym, oddano do użytku 170,7 km autostrad. Zatem wyniki były dość mierne, gdyż średniorocznie 
budowano tylko $57 \mathrm{~km}$ autostrad, a np. w 2010 roku oddano do ruchu zaledwie $10 \mathrm{~km}$ autostrad. Jednak $\mathrm{w}$ stosunku do wcześniejszego okresu postęp był widoczny. Między 1991 a 2004 rokiem budowano przeciętnie $31 \mathrm{~km}$ autostrad rocznie. Zdecydowanie większych rezultatów w budownictwie autostrad spodziewano się w latach 2011-2012, bezpośrednio przed Euro 2012.

Tabela 1. Odcinki autostrad oddane do użytku w latach 2008-2012

\begin{tabular}{|c|c|c|}
\hline Odcinek autostrady & Długość (w km) & Data oddania do użytku \\
\hline \multicolumn{3}{|l|}{ A1 } \\
\hline Rusocin-Swarożyn & 24,3 & 22 grudnia 2007 r. \\
\hline Swarożyn-Nowe Marzy & 63,9 & 17 października 2008 r. \\
\hline Nowe Marzy-Czerniewice & 62,4 & 14 października 2011 r. \\
\hline Kowal-Łódź Północ & 75,2 & 13 listopada 2012 r. \\
\hline Węzeł Łódź-Północ (A2) & 4,8 & 13 listopada 2012 r. \\
\hline Pyrzowice-Piekary Śląskie & 16,1 & 1 czerwca $2012 \mathrm{r}$. \\
\hline Piekary Śląskie-Zabrze Północ & 12,0 & 1 czerwca 2012 r. \\
\hline Zabrze Północ-Zabrze Zachód & 8,1 & 22 grudnia $2011 \mathrm{r}$. \\
\hline Zabrze Zachód-Sośnica (Gliwice) & 8,2 & 30 września $2011 \mathrm{r}$. \\
\hline Węzeł Sośnica (Gliwice) (A4) & 2,2 & 7 lipca 2010 r. \\
\hline Sośnica (Gliwice)-Bełk & 15,4 & 23 grudnia 2009 r. \\
\hline Bełk-Rowień & 7,5 & 15 grudnia $2010 \mathrm{r}$. \\
\hline Rowień-Świerklany & 6,6 & 21 kwietnia $2011 \mathrm{r}$. \\
\hline Mszana-Gorzyczki & 11,1 & 30 listopada 2012 r. \\
\hline \multicolumn{3}{|l|}{ A2 } \\
\hline Świecko-Nowy Tomyśl & 105,9 & 1 grudnia $2011 \mathrm{r}$. \\
\hline Stryków-Łódź Północ & 1,7 & 22 grudnia 2008 r. \\
\hline Węzeł Łódź-Północ (A1) & 2,6 & 3 czerwca 2012 r. \\
\hline Łódź Północ-Konotopa & 91 & 6 czerwca 2012 r. \\
\hline Obwodnica Mińska Mazowieckiego & 20,8 & 29 sierpnia 2012 r. \\
\hline \multicolumn{3}{|l|}{ A4 } \\
\hline Zgorzelec-Krzyżowa & 49,7 & 14 sierpnia $2009 \mathrm{r}$. \\
\hline Wielicka (Kraków)-Szarów & 19,9 & 28 października 2009 r. \\
\hline Szarów-Tarnów Krzyż & 56,9 & 29 listopada 2012 r. \\
\hline Rzeszów Północ-Rzeszów Wschód & 6,9 & 10 września 2012 r. \\
\hline \multicolumn{3}{|l|}{ A8 } \\
\hline Obwodnica Wrocławia & 22,4 & 31 sierpnia $2011 \mathrm{r}$. \\
\hline
\end{tabular}

Źródło: Zestawienie własne na podstawie: http://www.skyscrapercity.com/showthread.php?t=345003

I rzeczywiście przyrost był imponujący: w 2011 roku oddano do eksploatacji $214 \mathrm{~km}$ autostrad, a w roku 2012 - $299 \mathrm{~km}$. W 2011 roku dominowały efekty budów w systemie PPP, zaś w 2012 roku projektów finansowanych przez państwo. Na koncesjonowanym fragmencie autostrady A1 (Amber One) 14 października 2011 roku, w obecności ministra Grabarczyka, otwarto odcinek Nowe Marzy-Czerniewice liczący ponad $62 \mathrm{~km}$. Autostrada, która wraz z wcześniej otwartym odcinkiem 
połączyła Trójmiasto z Toruniem, wyposażona była w 8 MOP-ów. Prezydent Bronisław Komorowski otworzył koncesjonowany fragment A2 od Świecka do Nowego Tomyśla. Autostrada o długości 106 km została oddana do użytku 1 grudnia 2011 roku z pełnym wyposażeniem infrastrukturalnym

Z odcinków budowanych w systemie tradycyjnym (budżetowym) 21 kwietnia 2011 roku otwarto odcinek A1 Rowień-Świerklany, 30 września Zabrze Zachód-Sośnica (Gliwice), a 22 grudnia Zabrze Północ-Zabrze Zachód o łącznej długości $23 \mathrm{~km}$. 31 sierpnia ukończono oddawaną do użytku fragmentami obwodnicę Wrocławia (A8) o długości $22 \mathrm{~km}$.

W 2012 roku na skutek piętrzących się problemów dopiero na dwa dni przed otwarciem Euro 2012 oddano do ruchu całą autostradę A2 między Łodzią a Warszawą. Udostępnianie odbywało się stopniowo bez zwyczajowych ceremonii z udziałem władz państwowych. O świcie 23 maja kierowcy przejechali liczący 7,1 km, położony najbliżej Warszawy, odcinek E między węzłami Konotopa i Pruszków. W niedzielę 27 maja dopuszczono ruch na odcinku D z Pruszkowa do Grodziska Mazowieckiego o długości 17,6 km. Powstał w ten sposób pierwszy mazowiecki odcinek A2 o długości $25 \mathrm{~km}$. Droga pozbawiona była podstawowej infrastruktury obsługi podróżnych. Nie były przygotowane MOP-y w pobliżu Brwinowa, po paliwo należało zjeżdżać do Pruszkowa lub Grodziska Mazowieckiego. Dnia 3 czerwca udostępniono odcinek A, leżący najbliżej Łodzi i częściowo odcinek B. Kierowcy mogli przejechać od węzła Łódź Północ do węzła Skierniewice o łącznej długości $33 \mathrm{~km}$, jednak z ograniczoną do $70 \mathrm{~km} /$ godz. prędkością, co było następstwem braku warstwy ścieralnej. $Z$ tego samego powodu dopuszczono tylko ruch samochodów osobowych i autokarów. Ostatni odcinek C (i fragment odcinka B) udostępniono 6 czerwca, bez ważnego węzła w Wiskitkach.

Z tej okazji w mediach masowo pojawiały się informacje o połączeniu autostradą Warszawy z Berlinem albo Polski z Europą. Władze mogły odnotować spektakularny sukces, który propagandowo przykrył porażki na autostradach A1, A4 i A18. Na plan dalszy zeszły fakty odnoszące się do stanu nawierzchni i braków w infrastrukturze obsługi podróżnych, a przede wszystkim akcyjności w realizacji tego ważnego projektu. Przed klęską i wstydem uchroniła władze pospieszna nowelizacja prawa drogowego i wprowadzenie terminu „przejezdność".

Latem 2012 roku, już po zakończeniu Euro 2012, kontynuowano prace wykończeniowe między Łodzią a Warszawą. Roboty koncentrowały się na układaniu brakującej warstwy ścieralnej, dokończeniu budowy węzła Wiskitki oraz zakładaniu ekranów dźwiękochłonnych, wykańczaniu obiektów mostowych, budowy wjazdów awaryjnych oraz wjazdów i wyjazdów z nielicznych MOP-ów, elementów bezpieczeństwa ruchu drogowego i oznakowania autostrady. Do połowy października 
2012 roku występowały liczne utrudnienia w ruchu i ograniczenia prędkości. Do końca roku nie było stacji paliwowych i na ponad 90-kilometrowej trasie działały tylko dwa prymitywnie wyposażone MOP-y w rejonie Bolimowa.

W okresie, w którym otwierano poszczególne odcinki autostrady z Łodzi do Warszawy, na południu kraju 1 czerwca uruchomiono fragment A1 z Pyrzowic do Zabrza. Trasa licząca $28 \mathrm{~km}$ połączyła katowickie lotnisko z centrum Górnego Śląska i dalej ze skrzyżowaniem A1 i A4 w rejonie Gliwic. W ostatnich dniach lipca 2012 roku oddano do użytku fragment A2 na wschód od Warszawy. Licząca $21 \mathrm{~km}$ autostradowa obwodnica Mińska Mazowieckiego zdecydowanie odciążyła miasto od ruchu tranzytowego i stała się zaczątkiem autostrady łączącej Warszawę z granicą polsko-białoruską.

Na początku września 2012 roku włączono do ruchu liczący $6,9 \mathrm{~km}$ odcinek autostrady A4 między węzłami Rzeszów Północ i Rzeszów Wschód. Droga stanowiła pierwszy fragment autostrady A4 na terenie Podkarpacia. Pod koniec listopada 2012 roku udało się uruchomić z ograniczeniami 57-kilometrowy odcinek SzarówTarnów. Od węzła Szarów do Brzeska oraz od węzła Tarnów-Zachód do węzła Tarnów Krzyż ruch puszczono dwoma jezdniami, zaś od Brzeska do węzła Tarnów-Zachód jedną jezdnią. Ze względu na trwającą budowę uniemożliwiono przejazdy pojazdom powyżej 12 t oraz występowały ograniczenia prędkości.

Większe utrudnienia spotykały kierowców na najdalej na południe wysuniętym odcinku autostrady A1 między Świerklanami a Gorzyczkami. W końcu listopada 2012 roku otwarto tylko 10-kilometrowy fragment Mszana-Gorzyczki. Na przeszkodzie w udostępnieniu całego odcinka stanęła nieprzejezdność mostu w Mszanie, którego wykonawca prowadził działania naprawcze, zgodnie z decyzjami nadzoru budowlanego. W konsekwencji między Mszaną a Świerklanami ruch, zamiast autostradą, prowadzony był drogami wojewódzkimi. Ciągle nie można było dojechać autostradą z Górnego Śląska na teren Czech. W środkowej Polsce w połowie listopada otwarto 75-kilometrowy odcinek z Łodzi do Kowala na autostradzie A1 w kierunku Gdańska. Do dyspozycji kierowców przygotowano 8 miejsc obsługi podróżnych. Nowy odcinek autostradowy umożliwił ominięcie zatłoczonego Zgierza i Łęczycy, ale zmuszał po dojeździe do węzła Kowal do korzystania z zatłoczonej drogi krajowej nr 1, aby dostać się do podtoruńskich Czerniewic, gdzie zaczynał się północny odcinek A1.

Po uzyskaniu 6 czerwca 2012 roku „przejezdności” na odcinku A2 z Łodzi do Warszawy sieć autostrad w Polsce osiągnęła długość $1195 \mathrm{~km}$. Do końca roku oddano do użytku przeszło $175 \mathrm{~km}$, co dało 1370,4 km eksploatowanych autostrad. Na ogólną sieć składały się odcinki autostrady A1 o łącznej długości 335,3 km, A2 - 474,1 km, A4 - 510,3 km, A6 - 23,8 km, A8 - 22,4 km i A18 - 4,9 km. Najdłuższymi ciągami 
autostradowymi były odcinek A4 od granicy z Niemcami do Tarnowa długości 503 $\mathrm{km}$ i odcinek A2 od granicy zachodniej państwa do Warszawy długości $453 \mathrm{~km}$. Najdłuższy odcinek na A1 z Gdańska do Torunia liczył 151 km.

\section{Rysunek 1. Długość autostrad w Polsce w latach 2007-2012 (w km)}

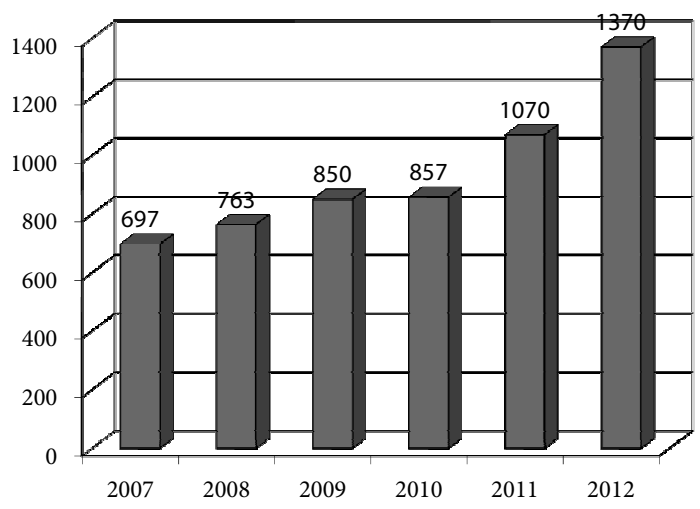

Źródło: http://www.skyscrapercity.com/showthread.php?t=345003

Mimo znacznego przyrostu długości autostrad w latach 2011-2012 program budowy związany z Euro 2012 nie został zrealizowany. Z planowanych $423 \mathrm{~km}$ autostrady A1 nie zdołano wybudować aż $315 \mathrm{~km}$. Analogicznie na autostradzie A4 zamiast $297 \mathrm{~km}$ oddano do ruchu tylko $74 \mathrm{~km}$. W całości powstały zaplanowane fragmenty autostrady A2 o łącznej długości $197 \mathrm{~km}$ i 22,4 km autostrady A8. Nie powstała autostrada A1 między Toruniem a Górnym Śląskiem oraz podstawowy odcinek A18 do granicy z Niemcami. Nie zbudowano autostrady A4 od Krakowa do granicy z krajem współorganizatorem Mistrzostw Europy - Ukrainą. Na przeszkodzie stanęły powodzie, przedłużające się badania archeologiczne, protesty ekologów i pojawiające się trudności finansowe, a przede wszystkim błędy w sferze przygotowań i wykonawstwa. Specjaliści drogowi wskazywali na poważne wady systemu i praktyki zamówień publicznych, których konsekwencją były bankructwa przedsiębiorstw wykonawczych. Przewidywali, że negatywne konsekwencje programu autostradowego na Euro 2012 wystąpią przez kilka kolejnych lat.

Interesujące może być porównanie dynamiki budowy dróg samochodowych w latach 2007-2011 (dla 2012 roku brak porównywalnych danych) w państwach o zbliżonej do Polski długości sieci autostradowej w punkcie wyjścia. Dowodzi ono niekwestionowanego przyspieszenia inwestycyjnego w naszym kraju w związku z organizacją Euro 2012, które umożliwiło prześcignięcie niektórych porównywanych państw na początku drugiej dekady XXI wieku. Jednak zdecydowanie wyprzedzały 
nas Węgry i mała Chorwacja, które jednak w 2007 roku miały dłuższą od polskiej sieć autostrad.

Rysunek 3. Rozwój sieci autostrad w wybranych państwach Europy w latach 2007-2011 (w km)

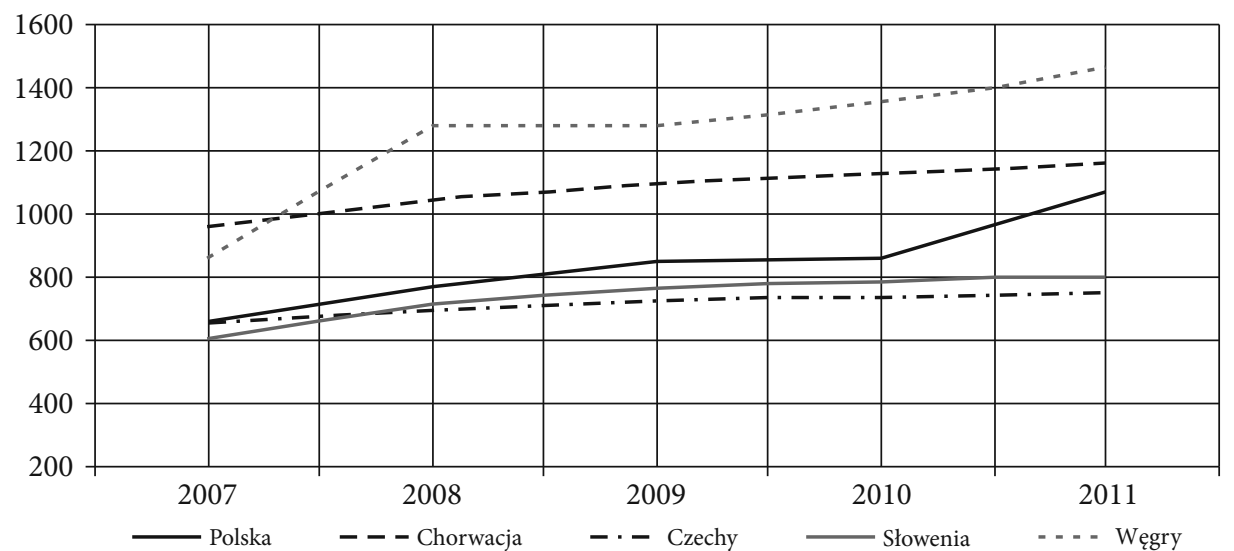

Źródło: http://portal.euromonitor.com/Portal/Pages/Statistics/Statistics.aspx

W celu uzyskania porównywalności danych posłużymy się wskaźnikiem udziału autostrad w całej sieci dróg publicznych danego państwa. W Polsce omawiany wskaźnik w 2006 roku osiągnął 0,2\% i utrzymał się na tym poziomie do końca 2010 roku. Dopiero w 2011 roku w związku z programem autostradowym na Euro 2012 podniósł się do 0,3\%. Kwalifikowało to jednak Polskę do grupy krajów najsłabiej wyposażonych w nowoczesne drogi samochodowe w regionie. Porównywane państwa, poza Słowenią, miały wskaźniki wyższe (Chorwacja aż 3,9\%, Węgry - 0,7\%, Czechy - 0,6\%). Duży dystans dzielił nasz kraj od państw, które już wcześniej swój awans gospodarczy osiągnęły dzięki członkostwu w UE - Portugalii $(3,3 \%)$ i Hiszpanii $(2,2 \%)$.

Znana w Polsce od lat „akcyjność” przy podejmowaniu wielkich projektów inwestycyjnych z całą siłą wystąpiła w okresie przygotowań do Euro 2012. Budowa autostrad przebiegała $\mathrm{w}$ warunkach niedostatecznego przygotowania i pośpiechu realizacyjnego. Wystąpiły poważne problemy w relacjach między państwowym inwestorem a prywatnymi wykonawcami, mnożyły się zjawiska patologiczne. Nieprzestrzegane były często rygory techniczne i finansowe, których negatywne skutki zostały ujawnione lub pojawią się za kilka lat. Klęskę poniosły próby finansowania autostrad w systemie PPP. Doszło do poważnej zapaści w sektorze budownictwa drogowego, a przede wszystkim wydłużenia okresu realizacji perspektywicznego 
programu autostradowego. Mimo ewidentnego powiększenia sieci dróg samochodowych przed Euro 2012, udział autostrad w całej sieci drogowej lokuje Polskę na dalekim miejscu w Europie.

\section{Highways for Euro 2012}

The decision to organize Euro 2012 in Poland was a challenge in the sphere of construction of economic infrastructure. Particular emphasis was put on construction and modernization of road network. The highway construction program that begun in 2006 was sped up and its priorities were slightly changed. However, when the Euro 2012 approached financial, environmental and construction problems were noticed. Many contracts were not realistic which caused arguments between the authorities and the building contractors. As a result the important and prestigious highway between Łódź and Warsaw was conditionally operational two days before the first match.

In spite of addition of $500 \mathrm{~km}$ of roads between 2011-2012 the highway construction program was not finished according to the plans. There were $423 \mathrm{~km}$ of A1 highway (Gdansk-border with Czech Republic) planned but $315 \mathrm{~km}$ were not build on time. Situation was similar on the A4 highway (German border-Ukrainian border) were instead of $297 \mathrm{~km}$ of roads only $74 \mathrm{~km}$ were finished. The only fragments that were finished as planned were $197 \mathrm{~km}$ on the A2 highway (German border-Warsaw) and 22,4 km of the A8 highway (Wrocław beltway).

\section{Les autoroutes pour l'Euro 2012}

Lorganisation du Championnat d'Europe de football 2012 en Pologne est devenue un défi dans le domaine du développement des infrastructures économiques dans ce pays. Une attention particulière a été accordée au développement et à la modernisation du réseau autoroutier. Mis en œuvre en 2006, le programme de construction d'autoroutes a été accéléré et ses priorités légèrement modifiées. Cependant, au fil du temps, il y a eu des problèmes financiers, d'environnement et de construction. De nombreux contrats se sont avérés être impossibles à mettre en œuvre. Il y a eu des différends entre les autorités routières et les entrepreneurs. Beaucoup d'entreprises ont fait faillite ou ont été en difficulté financière. Des appels d'offres ont été organisés pour sélectionner de nouvelles entreprises de 
construction. En conséquence, une autoroute importante entre Lodz et Varsovie a été ouverte (avec des restrictions à la circulation) deux jours avant le premier match.

Bien que la longueur des autoroutes ait augmenté de plus de $500 \mathrm{~km}$ en 2011-2012, le programme de construction d'autoroutes pour l'Euro 2012 n'a pas été réalisé. On n’a pas construit les $315 \mathrm{~km}$ de l'autoroute A1 (Gdansk-frontière tchèque) des $423 \mathrm{~km}$ prévus. D’autre part, dans le cas de l'autoroute A4 (frontière avec l'Allemagne-frontière avec l'Ukraine) seulement $74 \mathrm{~km}$ au lieu des $297 \mathrm{~km}$ ont été construits. Le succès était de construire une partie de l'autoroute A2 (frontière allemande-Varsovie) d'une longueur de $197 \mathrm{~km}$ et une partie de l'autoroute A8 d'une longueur de 22,4 km (contournement de Wrocław). 